Journal of Extension Education

Vol. 28 No. 2, 2016

\title{
Constraints Encountered by the Beneficiaries of Krishi Vigyan Kendra in North Eastern Region of India
}

\author{
Dipak Nath', P. K. Jain ${ }^{2}$, R. K. Talukdar ${ }^{3}$ and B.S. Hansra ${ }^{4}$
}

\begin{abstract}
The study was conducted among 200 farmers of ten purposively selected Krishi Vigyan Kendras (KVKs) in North Eastern region of India. The respondents were interviewed using a questionnaire for identifying the constraints and their suggestions for future improvement of KVK activities. The study revealed that unavailability of labour, unavailability of good quality seed and other inputs, unavailability of information about pest and disease management at right time,(inability to purchase modern agricultural implements and lack of capital were the major constraints. The respondents suggested that timely availability of seed and other inputs, regular and continuous monitoring, linking farmers to financial institutuions for financial support, and more long term practical oriented training programme are important for strengthening KVK activities.
\end{abstract}

Keywords : KVK, Constraints, Suggestions, North Eastern India.

Krishi Vigyan Kendra (KVK) is an innovative science-based institution in India with a mandate of Technology assessment, refinement and demonstration of technology/products. KVKs undertake need based training/ vocational training of farm-men, farm women and rural youths; conducts on farm trials for technology refinement and frontline demonstrations to demonstrate the latest agricultural technologies to the farmers as well as the extension workers, work as resource and knowledge centre of agricultural technology for supporting initiatives of public, private and voluntary sector for improving the agricultural economy of the district besides sale of seeds and planting materials to the farmers. Imparting learning through "work experience" to those who are engaged in farming is the main purpose of the KVKs. The syllabus and programme of each KVK are tailored to the felt needs of the farmers, resources and potential for agricultural growth in a particular area. "Seeing is believing" and "Learning

1.Subject Matter Specialist (Agril. Extension), Krishi Vigyan Kendra, West Tripura and Ph.D., Scholar, School of Agriculture, IGNOU, New Delhi 2.Assistant Professor, School of Agriculture, IGNOU, New Delhi 3.Professor, Dept. of Extension Education, Faculty of Agriculture, Assam Agricultural University, Jorhat, Assam and 4. Professor Emeritus (Agriculture), Amity International Centre for PHT and CCM, Amity University, Noida, Uttar Pradesh 
by doing" are the main methods of imparting skill training. Emphasis is also on employment generation to bring about equality of opportunities for socio economically deprived class of farmers and traditionally backward areas in the country including dry land areas (Venkatasubramanian et. al., 2009). North Eastern Region has 78 KVKs , out of which 18 nos. are under ICAR Institutes, 27 are under SAUs/ CAUs / GUs, three are under Non - Governmental Organizations (NGOs) and 30 are under State Governmental Departments.

KVKs have been implementing their mandated activities covering the farm men, farm women, and educated youth in a district. In view of this, for better implementation of mandated activities there is an urgent need to study the constraints encountered by the beneficiaries of KVKs and their suggestions for future improvement of KVK activities. Hence, the present study was conducted among the beneficiary farmers of KVKs in the North - East (NE) region.

\section{METHODOLOGY}

The objective of the study was to find out the constraints encountered by KVK beneficiaries and invite suggestions to address those constraints. For the study, ten KVKs were selected purposively from NE Region under different administrative units viz., SAU/ CAU, State govt. departments, ICAR and NGO. The purposively selected KVKs were
Cachar (SAU), Tinsukia (SAU), Imphal East (CAU), Phek (ICAR), West Garo Hills (ICAR), South Tripura (ICAR), Tirap (State dept.), Mammit (State dept.), South Sikkim (State dept.) and West Tripura (NGO). A sample of 200 beneficiaries was selected purposively from the ten KVKs. The respondents were interviewed with a structured questionnaire for identifying the constraints and their suggestions for strengthening the KVK activities.

\section{FINDINGS AND DISCUSSION}

The constraints encountered by the respondents are presented in Table 1 and their suggestions are highlighted in Table. 2. Data presented in Table 1 reveal that majority $(95.50 \%)$ of the respondents had reported "unavailability of labour" as the major constraint. Other major constraints, were "unavailability of good quality seed and other inputs" "unavailability of information about pest and disease management at right time", "Inability to purchase modern agricultural implements", "lack of capital" and "unavailability of timely credit facilities". The possible reason behind the major constraint, "unavailability of labour" might be due to the implementation of Mahatma Gandhi National Rural Employment Guarantee Act (MGNREGA) (Reddy et. al., 2014). The constraint, "unavailability of good quality seed \& other inputs" might have been experienced due to the remoteness of the region (North East Region) and the large area of jurisdiction of KVK. These 
Table 1

Constraints Encountered by Beneficiaries of KVK

$(\mathrm{N}=200)$

\begin{tabular}{|c|l|c|c|c|}
\hline $\begin{array}{r}\text { S1. } \\
\text { No. }\end{array}$ & \multicolumn{1}{|c|}{ Constraints } & Frequency & Percentage & Rank \\
\hline 1. & No assured irrigation & 113 & 56.50 & VIII \\
\hline 2. & Unavailability of timely credit facilities & 132 & 66.00 & VI \\
\hline 3. & Unawareness of govt. subsidy programme & 78 & 39.00 & X \\
\hline 4. & Unavailability of labour & 191 & 95.50 & I \\
\hline 5. & $\begin{array}{l}\text { Unavailability of good quality seed and } \\
\text { other input }\end{array}$ & 172 & 86.00 & II \\
\hline 6. & High cost of agricultural chemicals & 109 & 54.50 & IX \\
\hline 7. & $\begin{array}{l}\text { Inability to purchase modern agricultural } \\
\text { implements }\end{array}$ & 145 & 72.50 & IV \\
\hline 8. & High labour wages & 125 & 62.50 & VII \\
\hline 9. & Lack of capital & 142 & 71.00 & V \\
\hline 10 & $\begin{array}{l}\text { Unavailability of information about pest } \\
\text { and disease management at right time }\end{array}$ & 159 & 79.50 & III \\
\hline
\end{tabular}

Table 2

Suggestions for Future Improvement of KVK Programmes

$(\mathrm{N}=200)$

\begin{tabular}{|c|l|c|c|c|}
\hline $\begin{array}{r}\text { S1. } \\
\text { No. }\end{array}$ & \multicolumn{1}{|c|}{ Suggestions } & Frequency & Percentage & Rank \\
\hline 1. & Provision of assured irrigation & 109 & 54.50 & IV \\
\hline 2. & $\begin{array}{l}\text { Timely availability of seed and other } \\
\text { inputs }\end{array}$ & 178 & 89.00 & I \\
\hline 3. & KVK farm to be made a model farm & 87 & 43.50 & VII \\
\hline 4. & $\begin{array}{l}\text { More nos. of exposure visit, } \\
\text { awareness programme etc. }\end{array}$ & 81 & 40.50 & VIII \\
\hline 5. & $\begin{array}{l}\text { More long term practical oriented } \\
\text { training programme }\end{array}$ & 101 & 50.50 & V \\
\hline 6. & $\begin{array}{l}\text { KVK should be equipped with more } \\
\text { manpower }\end{array}$ & 70 & 35.00 & IX \\
\hline 7. & $\begin{array}{l}\text { Linking farmers to financial } \\
\text { institutions for financial support }\end{array}$ & 144 & 72.00 & III \\
\hline 8. & Linking farmers to other organizations & 97 & 48.50 & VI \\
\hline 9. & Regular and continuous monitoring & 154 & 77.00 & II \\
\hline
\end{tabular}


constraints could be addressed through collaboration with various government agencies and by motivating farmers to produce and use low cost inputs like biofertilizers and other organic manures thereby reducing the use of external inputs.

Suggestions from the respondents to overcome their constraints are presented in Table 2. Major suggestions are, "timely availability of seed \& other inputs" (89.00 \%); "regular and continuous monitoring" (77.00 \%), "linking farmers to financial institutions for financial support" (72.00\%) and "provision of assured irrigation" (54.50 \%) Most of the suggestions could to be implemented by organizing more training programmes, exposure visits, method demonstrations, production of sufficient quantities of seed $\&$ planting material and convergence with other line departments.

\section{REFERENCES}

Reddy, N., D, Reddy, A, A., Nagaraj, N, \& Bantilan, M, C, S (2014). Impact of Mahatma Gandhi rural employment gurantee Act (MGNREGA) on Rural labour markets, Hyderabad: ICRISAT CGIAR. 